\title{
TORT LIABILITY TO THOSE INJURED BY NEGLIGENT ACCREDITATION DECISIONS
}

\author{
PETER H. SCHUCK*
}

\section{INTRODUCTION}

From a public policy perspective, there is much to be said for using private accrediting bodies to help government agencies provide, subsidize, or regulate social service programs. Information about the nature of health, educational, and other social services is a public good; unless the government develops and disseminates this information itself or provides sufficient incentives for private entities to do so, not enough of it will be produced. These services, moreover, are usually supplied in an intensely politicized environment in which powerful interests are motivated to distort and even suppress programmatic information. Hence, policies to enlist private, nonprofit groups ${ }^{1}$ in producing and distributing information about the quality of social services may be highly desirable.

Private accreditation has other potential advantages. Efficiency gains due to lower personnel or process costs may be possible, especially if the government encourages competition in the provision of accreditation services; superior quality of accreditation may also result. Even more important in the long run are the effects of private accreditation on the quality of the underlying social services, as it can encourage more diverse and innovative approaches to their design, delivery, and appraisal. Private accreditation can also help to make government providers, payors, and regulators more accountable and responsive to the general public than is likely when they in effect evaluate their own efforts.

Accreditation decisions, however, will sometimes harm the interests of an individual or firm that relies upon it or is evaluated or otherwise affected by it. Two groups are most at risk. Consumers of a service that was improperly accredited may suffer physical or economic harm, and service providers denied accreditation may suffer competitive or economic loss, including reputational damage. Although an accreditor may under certain circumstances face liability

\footnotetext{
Copyright $\odot 1995$ by Law and Contemporary Problems

* Simeon E. Baldwin Professor of Law, Yale Law School. Nicole Stelle, Yale Law School class of 1995, provided research assistance.

1. Private accreditors used by government agencies are almost invariably organized in the nonprofit form, although some for-profit accreditors are presumably able to perform as well as or better than some of their nonprofit counterparts. See generally Henry Hansmann, The Role of Nonprofit Enterprise, 89 YALE L.J. 835 (1980).
} 
under contract, antitrust, or civil rights law, this paper is concerned only with its potential liability for damages in tort. ${ }^{2}$

Government agencies sometimes make accreditation decisions themselves, formulating and applying quality standards for service providers and granting or denying eligibility for insurance payments as a result. ${ }^{3}$ This paper, however, concerns the presumably more common arrangement in which these decisions are made by private accreditation bodies operating under contract with, and at the behest of, the government. This public-private interaction affects the structure of accreditor liability in several ways. Since the government is the ultimate "deep pocket," its involvement may attract more and larger claims by injured consumers. ${ }^{4}$ Moreover, its involvement may alter the accreditation decision's legal status by qualifying the decision as "state action" that triggers constitutionally based remedies.

On the other hand, government decisions about providing, subsidizing, or regulating social services may either be legally immune from liability or subject to statutorily limited damages. ${ }^{5}$ Even if the government cannot invoke immunity, consumers may lack standing or otherwise have limited opportunity to challenge the government's decision legally. ${ }^{6}$ Claimants may therefore sue the private accreditor, which may in turn seek to wrap itself in the government's immunity by invoking a kind of government contractor defense. ${ }^{7}$ Especially if this shared immunity is unavailable to accreditors, the possibility that both government entities and officers will enjoy tort immunity in cases challenging accreditation decisions places a special burden on the remaining tort claims against the accrediting agency to further the deterrence objectives that the immunities undermine. If the tort system is to ensure that the social costs of

2. Other papers in this symposium are concerned with consumer or competitor antitrust or civil rights claims under 42 U.S.C. $\$ 1983$ (1988). See generally Peter H. Brody \& Clark C. Havighurst, Accrediting and the Sherman Act, 57 LAW \& CONTEMP. PROBS. 199 (Autumn 1994); Eleanor D. Kinney, Private Accreditation as a Substitute for Direct Government Regulation in Public Health Insurance Programs: When Is It Appropriate?, 57 LAW \& CONTEMP. PROBS. 47 (Autumn 1994). Consumers could conceivably assert claims as third-party beneficiaries of the contract between the government and the accrediting body, but such claims are unlikely to succeed. See, e.g., State v. Joint Comm'n on Accreditation of Hosps., Inc., 470 So. 2d 169 (La. Ct. App. 1985). In any event, this theory would seem less attractive to plaintiffs than a straightforward tort claim.

3. Federal government regulation of nursing homes is an example.

4. See, e.g., AUDREY CHIN \& MARK A. PETERSON, DEEP POCKETS, EMPTY POCKETS: Who WINS IN COOK COUNTY JURY TRIALS 43 (1985) (finding that government defendants pay more than individual defendants and, for moderate injuries, more than corporate defendants).

5. See generally Peter SChuCK, SuIng Government: CITIZEN REMEdies fOR OfFicial WRONGS (1983) (discussing relationship between the liability of government and that of its individual officials).

6. See, e.g., O'Bannon v. Town Court Nursing Ctr., 447 U.S. 773 (1980) (ruling that Constitution does not entitle nursing home residents to pretermination hearing on government decision that could make subsidized care in that home unavailable).

7. See, e.g., Boyle v. United Technologies Corp., 487 U.S. 500 (1988). The availability of this defense to the accreditor seems doubtful, as it is not simply supplying a product or service according to government specifications, as in Boyle. Nevertheless, contractual protection of the accreditor against contribution or indemnity claims may be available. See generally Ronald A. Cass \& Clayton P. Gillette, The Government Contractor Defense: Contractual Allocation of Public Risk, 77 VA. L. REV. 257 (1991). 
poor accreditation decisions are internalized by those who can best minimize them, it must provide an effective cause of action against accreditors. Current tort law, however, may in fact be incapable of doing so.

At present, the risk of tort liability for accreditors appears to be very low. Because the case law involving consumer tort claims against private accreditors is exceedingly sparse,${ }^{8}$ most of this article is devoted to exploring and assessing other lines of cases that could conceivably provide analogical support for consumer claimants. The article's conclusion can be readily stated: only a single court has held a private accrediting body liable to a consumer for negligence in connection with its evaluation of a social service provider. ${ }^{9}$ Courts have invoked two main doctrinal principles to defeat liability: (1) a rule of no duty to incidental beneficiaries, and (2) demanding requirements that plaintiffs show detrimental reliance and increased risk. These principles largely reflect the traditional argument in favor of limiting liability to those in privity with the defendant; the notion is that privity limitations are necessary in order to avoid massive liabilities, overdeterrence, and high litigation costs. This argument also emphasizes the advantages that can be achieved by structuring legal relationships through contract rather than through tort law. ${ }^{10}$

Notwithstanding these arguments, however, some courts have rejected the traditional privity limitation and imposed liability on risk-increasing activities that can plausibly be analogized to accreditation. One category of cases involves technical groups like Underwriters Laboratories ("UL") which set product safety standards and provide public assurance of compliance with those standards; a more blatantly commercial endorsement of quality (the Good Housekeeping Seal of Approval) also triggered liability. Another category of cases involves other types of claims in which information flow is crucial to liability, notably claims against accountants for negligent financial reports on which the claimants relied. The principles underlying both groups of cases might be used by consumers to argue for accreditor liability under certain circumstances. This article concludes, however, that such an extension of tort liability would probably not further deterrence or compensation goals.

With respect to service providers complaining of denial of accreditation, this article's conclusion is so straightforward that it needs no further discussion below. In the very few tort cases brought by disappointed providers under

8. Only three relevant decisions reached the merits. Wissel v. Ohio High Sch. Athletic Ass'n, 605 N.E.2d 458 (Ohio Ct. App. 1992); State v. Joint Comm'n on Accreditation of Hosps., Inc., 470 So. $2 d$ 169 (La. Ct. App. 1985); Peterson v. Multnoman County Sch. Dist. No. 1, 668 P.2d 385 (Or. Ct. App. 1983).

9. See infra text accompanying notes 22-24 (discussing Peterson v. School Dist. No. 1, 668 P.2d 385). The few litigated cases generally involved claims of physical harm due to negligent accreditation. In one case brought on a negligent misrepresentation theory, students complained that undeserved accreditation of a business college that subsequently became defunct after they enrolled in it induced them to incur expenses and assume debt. This decision, however, failed to reach the merits. Jacobs v. Association of Indep. Colleges and Sch., 219 S.E.2d 837 (S.C. 1975).

10. These advantages include greater simplicity, predictability, and flexibility, lower risk of legal error, and less state coercion. 
theories of defamation or interference with contractual relations, their failure to show malice by the accreditor has defeated the claims. ${ }^{11}$ Given the strong first amendment interests in protecting the flow of information about the quality of social services, this malice requirement is likely to be especially demanding in view of the special constitutional protections for information disseminators. ${ }^{12}$ Hence, tort doctrine will give little comfort to disappointed service providers; they will have to look principally to antitrust law for protection. ${ }^{13}$

II

\section{CONSUMER Claims}

Several legal theories are available to consumers who seek to hold accrediting bodies liable in tort for their injuries. The most commonly invoked theory is negligence in the performance of the accreditation. An additional theory is that of negligent misrepresentation (that is, the misrepresentation of a material fact or opinion to another made for the purpose of inducing reliance and that in fact induces detrimental reliance). Because the legal concepts implicated by these theories largely overlap, the particular theory chosen by the plaintiff probably has little effect on case outcomes.

\section{A. Cases Involving Tort Claims Against Accreditors}

One of the three accreditation cases on point is State of Louisiana v. Joint Commission on Accreditation of Hospitals, Inc., ${ }^{14}$ which involved an allegedly negligent inspection and accreditation by the Joint Commission on Accreditation of Hospitals (the "JCAH") of a state hospital. The state argued that the JCAH, which it had paid to inspect the hospital for accreditation purposes, had failed to discover that the renal unit water purification system violated JCAH standards, resulting in injuries to patients for which the state had been obliged to pay. The court rejected the state's contract claim, finding that the JCAH inspector had determined that the hospital periodically tested the water system and reported the results, which was all that the pertinent JCAH standard required. ${ }^{15}$ Addressing the tort claim, the court stated that the JCAH owed a legal duty of care only to the hospital that paid for its survey and whose

11. See New Jersey Secretarial Sch., Inc. v. National Ass'n of Trade and Technical Sch., 597 F. Supp. 477 (D.D.C. 1984) (holding accrediting agency not liable absent evidence of malice or intent to injure); Avins v. White, 627 F.2d 637 (3d Cir. 1980) (holding former law school dean, as a public figure, must establish constitutional malice to support defamation claim against accrediting body).

12. See Bose Corp. v. Consumers Union of the United States, Inc., 466 U.S. 485 (1984) (requiring "clear and convincing proof of 'actual malice," not just preponderance of evidence); N.Y. Times v. Sullivan, 376 U.S. 254 (1964) (requiring proof of constitutionally defined malice).

13. See generally Clark Havighurst \& Nancy M. P. King, Private Credentialing of Health Care Personnel: An Antitrust Perspective (pt. 2), 9 AM. J.L. \& MED. 131 (1983); see also id. at 163-64 (noting possible unfair competition claims for competitor-sponsored credentialing decisions).

14. 470 So. 2 d 169 (La. Ct. App. 1985).

15. "JCAH did not undertake to guarantee the safe operation of the hospital or renal units. Neither did they agree to underwrite the competency of the [hospital staff]." Id. at 175. 
employees were responsible for the injury. Any benefit to the patients from the JCAH survey was "merely incidental"; 16 hence the JCAH owed them no duty.

Even if this view were dictum, ${ }^{17}$ the rule of no duty to incidental beneficiaries seems wholly unconvincing as a general legal principle, at least in the context of accreditation of social service programs that the government provides, subsidizes, or regulates. With hospital care, after all, the main point of accreditation is patient protection through quality control (that is, avoidance of malpractice). If service quality is inferior, injury to patients is a readily foreseeable consequence. Finally, the the principal purpose of the hospital's quality assurance system, through accreditation or otherwise, is to induce reliance on that system by the general public, insurers, and other payors. Much the same is true with quality control in educational institutions, mutatis mutandis. Although the no duty rule remains the law, it seems vulnerable to challenge in the accreditation area. This possibility is discussed below.

Section 324A of the Restatement (Second) of Torts supplies a somewhat different theory of accreditor liability than that pursued in $J C A H{ }^{18}$ This section recognizes a duty on the part of one who undertakes to render service to another, if the one undertaking the service (1) negligently increases the risk to a third person who is physically harmed thereby, or (2) "has undertaken to perform a duty owed by the other to the third person,"19 or (3) the harm results from reliance by the other or the third person in the undertaking. One would think that a court invoking these tests should have no difficulty in imposing liability on a professional accreditor when a negligent accrediting decision injures a consumer who relied on it to his detriment, at least where the accreditor could reasonably foresee that its negligence could harm the consumer.

What does it mean for a consumer to rely to his detriment on an accreditation decision? Again, the case law on negligent accreditation is so sparse that one cannot be certain. Judging from cases involving claims of negligent standard-setting, however, it appears that detrimental reliance requires a showing that the defendant acted affirmatively in a way that placed consumers at greater risk than if the defendant had not acted. This may perhaps be accomplished by showing that its standard was the only one in place or that it reduced the effectiveness of an already existing standard (as by supplanting, not merely

16. Id. at 178 .

17. The court found that on the facts, the JCAH's conduct was not negligent. It did so by finding the accreditor's duty satisfied by what appears to have been a rather perfunctory, checklist approach to the inspection, one which looked only for the mere existence of a control system without regard to how well the system actually operated. The JCAH is frequently criticized for conducting superficial inspections of this sort. See, e.g., Walt Bogdanich, Small Comfort: Prized by Hospitals, Accreditation Hides Perils Patients Face, WALL ST. J., Oct. 12, 1988, at A1.

18. The court in $J C A H$ noted that this common law principle had not been adopted in Lousiana. It preferred to decide the tort claim under the state's code provision. 470 So. $2 d$ at 176.

19. RESTATEMENT (SECOND) OF TORTS \& 324A (1965). 
supplementing, the existing standard or causing it to become less important) ${ }^{20}$ A similar requirement seems to apply to claims of negligent inspection. ${ }^{21}$

The importance of this detrimental reliance/increased risk requirement under the Restatement is illustrated by two cases-the only ones other than JCAH brought by consumers against social services accreditors. Although these two cases presented similar facts, the courts reached opposite decisions on the issue of liability. In the first case, Peterson v. Multnomah County School Dist. No. 1,22 a high school student who was injured on the second day of preseason football practice when tackling another student sued, inter alia, the Oregon School Activities Association (the "OSAA") for negligently failing to require or recommend that its member schools undertake various training and safety measures, including barring live tackling during the first week of practice. The OSAA, a private group, had adopted rules that were apparently binding on the schools and governed the timing of preseason practices but not the content of such practices. While disseminating safety-related information from other associations, it did not adopt or disseminate a recommendation of the National Federation of State High School Associations (the "NFSHSA") and the American Medical Association (the "AMA") that practice games be prohibited until at least the third week of practice. ${ }^{23}$ The court, relying on the common law rule that one who voluntarily undertakes to act on behalf of another must exercise due care, held that by undertaking to promulgate safety standards to protect student athletes and then neglecting the NFSHSA/AMA recommendation, the OSAA was negligent and thus liable. The court satisfied itself with a very weak detrimental reliance/increased risk requirement: it was enough for the court that although the school already had a rule in effect which, if followed, would have prevented the plaintiff's injury, the school might have complied with an OSAA recommendation (had it made one) ${ }^{24}$

The defendant prevailed, however, in a recent Ohio case in which the requirement of reliance/increased risk was much more demanding. ${ }^{25}$ There, an injured student sued the Ohio High School Athletic Association and other organizations and individuals that issued safety standards adopted by member schools. Invoking the same common law rule relied on in Peterson, the student alleged that the defendants negligently failed to educate him as to proper tackling techniques. The court denied liability on the ground that the student had not shown that he affirmatively and detrimentally relied on the defendants'

20. See, e.g., Wissel v. Ohio High Sch. Athletic Ass'n., 605 N.E.2d 458, 465-66 (Ohio Ct. App. 1992).

21. E.g., Canipe v. National Loss Service Corp., 737 F.2d 1055 (5th Cir. 1975) (holding duty based on both reliance and increased risk); Tillman v. Travelers Indem. Co., 506 F.2d 917 (5th Cir. 1975) (holding no duty because no reliance); see also Santillo v. Chambersburg, 603 F. Supp. 211 (E.D. Pa. 1985) (finding both reliance on and increased risk from safety inspection); Blessing v. United States, 447 F. Supp. 1160 (E.D. Pa. 1978) (holding OSHA inspection did not supplant employer's own safety inspection system; no finding of reliance or increased risk).

22. 668 P.2d 385 (Or. Ct. App. 1983).

23. Id. at 387.

24. Id. at 394.

25. Wissel, 605 N.E.2d at 465 . 
actions or representations either in the sense that he chose not to wear another, safer helmet (if one existed) because of those actions or representations or in the sense that he played or tackled differently because of them. ${ }^{26}$ The Ohio court, in contrast to the Oregon one, was unwilling to assume such reliance.

These three cases, then, constitute the entire reported case law involving tort claims against accreditors of social service programs. ${ }^{27}$ They indicate that a rule of no duty to incidental beneficiaries coupled with a robust requirement of detrimental reliance and increased risk make accreditor liability unlikely under existing law. ${ }^{28}$

\section{B. Analogies from Other Areas of Tort Law}

The following analysis draws upon judicial developments in other areas of tort law. In some of these areas, the courts have defined quite narrowly the scope of the duties owed by accreditor analogues to those not in privity with them, refusing to extend protection to injured consumers. But the courts have characterized the duty of the accreditor analogue much more broadly in a few contexts, including some in which the arguments for the privity requirement are even stronger than in the accreditation context. Since tort cases against accreditors per se are so few and far between, these analogous cases may provide important clues to how courts would decide these claims were they to be litigated and to how an argument for accreditor liability to third-party consumers could be cobbled together if a court so desired. ${ }^{29}$

What is common to these other cases and what makes them arguably relevant to negligent accreditation claims is their relatively expansive view of the scope of the legal duty owed by those who are paid to provide information about the quality of the condition or activity of another (usually the payor) in

26. Id. at $465-66$.

27. There are some unreported cases involving claims against the JCAH. See Timothy Jost, The Joint Commission on Accreditation of Hospitals: Private Regulation of Health Care and the Public Interest, 24 B.C. L. REV. 835, 859 n.219 (1983); see also Wissel, 605 N.E.2d 458.

28. Federal preemption is another defense that may defeat common law liability claims asserted against accreditors. See Keams v. Tempe Technical Inst., Inc., 807 F. Supp. 569 (D. Ariz. 1992) (dismissing on federal preemption grounds negligence claim by former students of bankrupt technical school against, inter alia, federally recognized educational accrediting agencies), appeal filed, 9 th $\mathrm{Cir}$. docket no. 92-16349.

29. In this effort to predict the future jurisprudential status of the traditional no duty rule, the erosion of the famous decision of H.R. Moch Co. v. Rensselaer Water Co., 159 N.E. 896 (N.Y. 1928), is of some interest. In Moch, Judge Cardozo held that water companies owe no legal duty to property owners who suffer fire-related injuries caused by inadequate water pressure. Although Moch is still commonly cited by courts to limit tort duties to injured parties not in privity with the injurer, some other courts have now rejected this rationale and upheld such third-party suits (at least for property damage claims) against water companies. E.g., Weinberg v. Dinger, 524 A.2d 366 (N.J. 1987). If the defense is being diluted or rejected in water company cases where it prevailed for so long, it may also be vulnerable in the accreditation context where the specter of massive liability, often invoked as a rationale for the no duty rule in the water company cases, is absent.

As noted below, the courts that uphold negligent accounting claims usually reject another Cardozo decision, Ultramares Corp. v. Touche, 174 N.E. 44 (N.Y. 1931), which limited accountants' duty to third parties for some of the same reasons advanced by Cardozo in Moch. 
circumstances in which third parties (consumers, investors, regulators, payors, or others) will (and are intended to) foreseeably and detrimentally rely on the accuracy of this information.

Since accrediting bodies usually adopt their own standards rather than simply applying those already established elsewhere, cases involving allegedly negligent standard-setting activity undertaken by private entities at the behest of either government or private groups may also be germane to our inquiry. In dealing with such standards, the courts are divided on the issue of liability to injured consumers. Some courts hold that a trade association promulgating general safety standards owes no duty of care to members of the public who use the products of trade association members. ${ }^{30}$ Others, however, have upheld consumers' claims. ${ }^{31}$

The courts are also divided in a related group of cases involving claims against testing organizations that furnish seals of approval. These groups often function much like accreditors in that they develop performance standards and then apply them to particular products, issuing their seals to those that comply. Some courts have upheld the claims of consumers injured by products bearing those seals. For example, liability was imposed in a case involving injury from negligently manufactured shoes bearing the "Good Housekeeping Seal of Approval." The court emphasized Good Housekeeping's voluntary involvement in the marketing process for its own gain, the loan of its reputation to the product through its endorsement, and the consumer's reliance upon this endorsement. ${ }^{32}$ Products bearing the UL seal have generated many suits, with mixed results. Some courts have denied liability, suggesting that UL owes a duty only to the manufacturer, not to the consumer. ${ }^{33}$ Others, however, have either upheld UL's liability to third-party consumers or indicated that they would do so on a proper factual showing. ${ }^{34}$

30. E.g., Harmon v. National Automotive Parts Ass'n, 720 F. Supp. 79 (N.D. Miss. 1989); Blalock v. Syracuse Stamping Co., 584 F. Supp. 454 (E.D. Pa. 1984); Meyers v. Donnatacci, 531 A.2d 398 (N.J. Super. Ct. Law Div. 1987). See generally Jack Bierig et al., Tort Liability Considerations for Medical Societies, in Legal ImpliCations of Practice Parameters 43, 45 (Am. Med. Ass'n ed., 1987).

31. E.g., King v. National Spa and Pool Inst., Inc., 570 So. 2d 612 (Ala. 1990) (holding that manufacturer's reliance on association's safety standard does not preclude the imposition of liability for injury suffered by consumer); see also, Benco Plastics, Inc. v. Westinghouse Elec. Corp., 387 F. Supp. 772,786 (E.D. Tenn. 1974) (holding UL owed no duty to corporation for economic harm but noting that result might be different for consumer claiming physical injury).

32. Hanberry v. Hearst Corp., 81 Cal. Rptr. 519 (Cal. Ct. App. 1969). Although the court found an increased risk to consumers in general, it made no specific finding about risk to the plaintiff.

33. E.g., Cantrell v. Amarillo Hardware Co., 602 P.2d 1326, 1328-29 (Kan. 1979) (UL not a proper party).

34. E.g., United States Lighting Serv., Inc. v. Llerad Corp., 800 F. Supp. 1513 (N.D. Ohio 1992) (holding UL owes duty to commercial installer of lighting system purchased by installer's client where defect causes economic harm; finding reliance on certification and increased risk to consumers in general); Hempstead v. General Fire Extinguisher Corp., 269 F. Supp. 109 (D. Del. 1967) (holding plaintiff injured by explosion of fire extinguisher while helping to put out fire could sue UL for negligence in inspecting, testing, and approving design); Peacocks, Inc. v. Shreveport Alarm Co., 510 So. $2 \mathrm{~d} 387$ (La. Ct. App. 1987) (holding UL liable for $20 \%$ of economic harm suffered by plaintiff store due to UL's negligent failure to assure burglar alarm system's compliance with UL's previously-issued 
Cases involving standard-setting and testing/certification might be distinguished from accreditation disputes on the ground that accreditation is a service primarily designed to assist service providers or payors in making their resource allocation and payment decisions, with any consumer protection effects being secondary, while the very purpose of product and service safety standards is to reduce the risks of injury to consumers. On this view, the traditional rule of no duty to third parties might be justified for accreditation even if it is not justified for standard-setting or testing/certification. On the other hand, it is not clear that this difference in purpose actually exists or is sufficiently great to warrant a different legal outcome.

Perhaps a closer analogy to accreditation is an accountant's certification of a client's financial condition. A number of courts hold that an accounting firm that negligently prepares financial reports for clients also owes a tort duty of care $^{35}$ to some third parties who may be expected to rely on those reports, even if the specific identity of the third parties is unknown to the accountants-or indeed to the accountant's client-and even if they are not in privity with either the accountant or the client. ${ }^{36}$ Like the accreditation of health care and educational services, the certification of financial condition is intended, inter alia, to exploit the power of information to induce public confidence in and reliance on the firm being described or evaluated. ${ }^{37}$ In each of these contexts, the subject of the information (that is, the hospital, educational institution, or accountant's client) procured the description or evaluation of its own activities not only for its internal use but also for the use of third parties.

Both financial reports and accreditation reports have public good attributes: those who produce and pay for the information cannot fully appropriate its social value. Without exactly saying so, traditional tort doctrine seems to have recognized and sought to accommodate this fact by establishing a rule that

certificate; finding reliance); Yassin v. Certified Grocers of Ill., 502 N.E.2d 315 (Ill. App. Ct. 1986) (holding UL owes duty to consumer, although not negligent on the facts; no finding of either reliance or increased risk); see also Toman v. Underwriters Lab., 707 F.2d 620 (1st Cir. 1983) (seeming to assume duty of UL to consumer to police the use of its approved marks; no findings concerning reliance or increased risk); Groppel Co., Inc. v. United State Gypsum Co., 616 S.W.2d 49, 66 (Mo. Ct. App. 1981) (seeming to assume duty by UL to consumer but finding no liability on the facts; no finding of either reliance or increased risk).

35. Again, this analysis is limited to tort claims. Accountant liability to third parties under the securities laws is already well-established.

36. E.g., International Mortgage Co. v. John P. Butler Accountancy Corp., 223 Cal. Rptr. 218 (1986); H. Rosenblum, Inc. v. Adler, 461 A.2d 138 (N.J. 1983). See generally. John A. Siliciano, Negligent Accounting and the Limits of Instrumental Tort Reform, 86 MiCH. L. REV. 1929 (1988) (criticizing these developments). For a recent summary characterization of the state of the law on this question, see Gary Schwartz, The Beginning and the Possible End of the Rise of Modern American Tort Law, 26.GA. L. REV. 601, 662 n.319 (1992).

37. In another case involving allegations of negligent accreditation inspection (here, of an educational institution), the South Carolina Supreme Court did not reach the merits but noted in passing that schools held out their accreditation as a way of attracting students, many students relied on accreditation in deciding which schools to attend, and accreditation was "also the basis and condition precedent to the making of thousands of dollars of student loans." Jacobs v. Association of Indep. Colleges and Sch., 219 S.E.2d 837, 839 (S.C. 1975). 
accountants owe no duty to third parties not in privity with them, even those harmed by relying on their negligent financial reports. ${ }^{38}$ This rule, which survives in many jurisdictions, has much to recommend it, and some commentators discern (and applaud) a very recent trend back in that direction (most notably in New York and California), although accountant liability to third parties evidently is continuing to expand in other areas, especially in the wake of thrift institution imbroglios. ${ }^{39}$

The traditional rule limiting accountant liability (and its underlying privity requirement) was largely grounded in the same kind of no-duty-to-incidentalbeneficiaries rationale advanced by the court to defeat accreditor liability in $J C A H^{40}$ The rule also reflected a related concern that accountant liability to third parties would generate economic loss claims that might be difficult to limit, predict, or insure against. In contrast, third-party claims against accreditors would not be confined to economic loss; in the health care area, at least, they would also include physical injuries, which might compound the problems growing out of uncertain damages. ${ }^{41}$

Some other areas of tort litigation that bear far less resemblance to the accreditation context may nevertheless suggest how future courts might resolve negligent accreditation claims. One example is the Tarasoff line of cases, which grew out of a now famous California decision in which a psychiatrist who learned (or reasonably should have concluded) that a dangerous patient intended to injure a third party had a duty to take reasonable steps to protect that individual. ${ }^{42}$ The Tarasoff principle has subsequently been extended well beyond the facts of that case to situations in which the third party could not be identified in advance. ${ }^{43}$

While cases of this sort may seem far removed from the accreditation context, they exemplify a principle that is common to both situations. In each, a victim claims that the defendant, although informed (or on notice) of a risk of physical injury to the victim posed by the subject of that information, failed to communicate it to the victim or to act upon it when such communication or action might have avoided the injury. In each, moreover, the creator of the risk

38. Ultramares Corp. v. Touche, 174 N.E. 441 (N.Y. 1931).

39. VICTOR P. GOLDBERG, RESTORING THE PRIVITY BARRIER FOR NEGLIGENT ACCOUNTANTS 2 (Center for Law and Economic Studies, Columbia Univ. School of Law Working Paper No. 93 (1993)); Victor P. Goldberg, Accountable Accountants: Is Third-Party Liability Necessary?, 17 J. LEGAL STUD. 295, 296 (1988); see also Siliciano, supra note 36.

40. See supra text accompanying notes 14-18.

41. There are, of course, some other differences, although their significance is not clear. For example, negligent accounting claims are typically asserted against for-profit companies, while negligent accreditation claims could apply to both for-profit and nonprofit entities (for example, schools and hospitals). In addition, one might want to control the scope of dissemination of financial information, but such control would defeat the central purpose of accreditation.

42. Tarasoff v. Regents of the Univ. of Cal., 551 P.2d 334 (Cal. 1976).

43. Indeed in one recent decision, the Delaware Supreme Court went so far as to uphold a $\$ 1.4$ million verdict against a state hospital psychiatrist who discharged a psychotic mental patient who almost six months later killed a pedestrian while driving a motor vehicle. Naidu v. Laird, 539 A.2d 1064, 1066 (Del. 1988). 
paid the defendant to gather the crucial information about risk; indeed, in the health care and education contexts, the risk creator-provider presumably selected the defendant-accreditor because of the latter's ability to induce both confidence and reliance on its judgment. In this respect, at least, the victim's claim seems even stronger than it is under a more conventional Tarasoff claim. It is true that in the accreditation setting, the risk creator (for example, a hospital) wants the information to be communicated to the third parties, while in the psychiatric setting, the risk creator (typically but not necessarily a patient $)^{44}$ presumably does not. This difference between the two situations, however, should not necessarily defeat liability. Indeed, the fact that liability is imposed in the psychiatric context despite a very powerful countervailing interest in respecting patient confidentiality ${ }^{45}$ is actually an argument $a$ fortiori for imposing liability on the accreditor. In the accreditation situation, after all, confidentiality is not a goal; instead, each party ex ante wants the information transmitted to all the world. ${ }^{46}$

Another category of tort litigation, negligent entrustment, is a somewhat weaker analog to accreditor liability but may still provide some support for accreditor liability. ${ }^{47}$ To characterize these cases tendentiously (that is, in terms that deliberately draw an analogy to the accreditation context), they involve situations in which $\mathrm{A}$, who knows (or should know) about the riskiness of B, nevertheless entrusts B with some instrumentality ${ }^{48}$ that interacts with B's risky propensity to injure $C$ (who is usually a stranger to both $A$ and $B$ ) in ways that A should have foreseen.

Another line of cases, of special interest because they involve hospital care, seems most explicable in negligent entrustment terms even if courts do not use such terms. In these cases, hospitals may be held liable for negligent selection, credentialing, and supervision of their medical staffs. ${ }^{49}$ These theories of liability are persuasive: when hospitals entrust their patients to incompetent physicians on their staffs, they place them at great risk of injury, risk that hospitals can control efficiently.

44. For example, the information could come from police or hospital records.

45. This interest is expressly addressed in Tarasoff and many of its progeny.

46. An intermediate situation might be one in which a factory owner's insurer inspects the factory and discovers a dangerous condition but fails to disclose it to a third party (usually a worker), who is injured by it. Although most courts do not uphold the insurer's liability in such cases, some do. Compare Smith v. Allendale Mut. Ins. Co., 303 N.W.2d 702 (Mich. 1981) (holding defendant not liable) with United States F \& G Co. v. Jones, 356 So. 2d 596 (Ala. 1978) (holding defendant liable).

47. For another effort to draw analogical inferences from this genre of cases, see Peter Schuck, Municipal Liability Under Section 1983: Some Lessons from Tort Law and Organization Theory, 77 GEO. L.J. 1753, 1768-72 (1989) (analyzing section 1983 liability for local police torts).

48. E.g., Vince v. Wilson, 561 A.2d 103 (Vt. 1989) (involving an automobile); Kelley v. R.G. Indus., Inc., 497 A.2d 1143 (Md. 1985) (involving a firearm; strictly speaking, this decision was decided on a manufacturer's product liability theory rather than on a negligent entrustment theory); Kelly $v$. Gwinnell, 476 A.2d 1219 (N.J. 1984) (involving alcohol).

49. The leading cases include Bell v. Sharp Cabrillo Hosp., 260 Cal. Rptr 37 (Cal. Ct. App. 1989); Johnson v. Misericordia Community Hosp., 301 N.W.2d 156 (Wis. 1981); Darling v. Charleston Community Memorial Hosp., 211 N.E.2d 253 (IIl. 1965). 
Negligent entrustment cases can be viewed as extensions of the Tarasoff principle, which holds that one who possesses risk information may be obliged to transmit or act upon it in order to protect strangers from harm. Again, one can certainly point to differences between accreditation and the contexts in which these cases arise. For example, an accreditor can avoid liability simply by doing nonnegligently what it is paid to do (that is, gather, evaluate, and disseminate information), while an entruster is ordinarily not paid to do these things yet is obliged to take some affirmative action to prevent the harm in order to avoid liability. As with Tarasoff-type claims, however, these differences may actually cut in favor of accreditor liability rather than against it.

III

\section{CONCLUSION}

Only a handful of tort cases involving consumer challenges to accreditation decisions exist, certainly too few to discern any cross-jurisdictional trend, and none of them contains much analysis. ${ }^{50}$ Consumers' claims of negligent accreditation are likely to be barred at the threshhold by a narrowly defined scope of legal duty for accreditors and by a robust requirement that consumers show detrimental reliance on, and increased risk from, the accrediting decision. As we have also seen, however, tort principles distilled from a variety of arguably analogous contexts may support liability to consumers. These principles establish that under certain circumstances, those who already possess risk information or who can readily gather it are under a legal duty to communicate it nonnegligently to strangers who, if so informed, could avoid harm to themselves. Injured consumers who can deploy these principles and adduce sympathetic facts might be able to overcome the traditional doctrinal obstacles to accreditor liability.

In order for consumers to succeed in this endeavor, however, the courts would have to impose new, more expansive liabilities. Given the vigorous reaction to the tort law innovations of the 1960s, 1970s, and early 1980s, it seems unlikely that this will occur in the near future. ${ }^{51}$ This fact, along with the existence of governmental and official immunity against claims of negligent accreditation, threatens to create a gap in the system of deterrence. In pointing to this gap, however, I do not mean to suggest that the tort system should necessarily be used to fill it. In thinking about this question, one should consider the substantial body of legal scholarship that casts doubt on the tort system's ability effectively to deter much of the negligent behavior that results in personal injuries. ${ }^{52}$

50. As noted at the outset, no cases involving disappointed service providers have been decided on the merits.

51. See Schwartz, supra note 36.

52. See, e.g., Stephen D. Sugarman, Doing Away with Personal Injury Law (1989). 
Before reaching a firm conclusion on the appropriate role of the tort system in influencing accreditation activity, then, one must first analyze a number of other issues well beyond the scope of this article, especially the relative efficacy and cost of other formal and informal sanctioning, regulatory, and compensatory techniques that might be brought to bear on the problem. Although the outcome of such an inquiry must of course await such an analysis, there are some excellent reasons to believe that tort law would not be a particularly effective deterrent to, much less a compensatory remedy for, negligent accreditation. A recently published comprehensive empirical study established that the tort system has performed very poorly in the area of medical malpractice, reaching only a small fraction of the actual incidents of malpractice, and at prohibitively high cost. ${ }^{53}$ If, 'as it seems likely, consumer claims for negligent accreditation of health care providers will be even more attenuated and difficult to prove than are direct malpractice claims against the providers themselves, the tort system will be of even less assistance to health care consumers who challenge accreditation decisions. In the case of accreditation of educational programs, it is safe to predict that consumers' claims will founder on courts' rejection of liability for the kind of educational malpractice to which accreditation decisions are most likely to be relevant. ${ }^{54}$ Finally, service providers can almost certainly pursue their remedies for injurious accreditation far more effectively through antitrust, civil rights, and (in the case of public agency decisions) administrative law, which speak directly to their complaints about competitive harm and procedural violations.

53. Harvard Medical Practice Study, Patients, Doctors, and Lawyers: Medical INJURy, MALPRACTICE LitIGATION, AND PATIENT COMPENSATION IN NEW YORK: REPORT OF THE Harvard Medical. Practice Study to the State of New York (1990).

54. E.g., Finstad v. Washburn Univ. of Topeka, 845 P.2d 685 (Kan. 1993) (holding no liability for accreditation decision); see also Ross v. Creighton Univ., 740 F. Supp. 1319 (N.D. Ill. 1990); Donohue v. Copaigue Unified Free Sch. Dist., 391 N.E.2d 1352 (N.Y. 1979). 
HeinOnline -- 57 Law \& Contemp. Probs. 1981994 